\title{
Coupling of Wind Energy and Biogas with a High Temperature Steam Electrolyser for Hydrogen and Methane Production
}

\author{
Nathalie Monnerie, Martin Roeb, Anis Houaijia, Christian Sattler \\ Institute of Solar Research, German Aerospace Center (DLR), Cologne, Germany \\ Email: nathalie.monnerie@dlr.de
}

Received 13 December 2013; revised 17 February 2014; accepted 12 March 2014

Copyright (C) 2014 by authors and Scientific Research Publishing Inc.

This work is licensed under the Creative Commons Attribution International License (CC BY).

http://creativecommons.org/licenses/by/4.0/

c) (†) Open Access

\section{Abstract}

The production of environment friendly green fuels is based on energy from renewable sources. Among the renewable sources, wind power is a very growing power technology. An example which has been discussed very widely is hydrogen which is an ideal fuel for a fuel cell. Hydrogen is the energy of the future. It will be used as energy carrier as well as reactant to produce green fuels, like methane which is easier to handle. Direct coupling of a High Temperature Steam Electrolyser (HTSE) with a wind turbine can be used to generate hydrogen. Indeed performing the electrolysis process at high temperatures offers the advantage of achieving higher efficiencies compared to the conventional water electrolysis. The hydrogen produced can be then reacted with the $\mathrm{CO}_{2}$ content of biogas to form methane as green fuel. Thus, the concept presented in this paper illustrates the potential of the HTSE technology coupled with a wind turbine, this system being combined with biogas in a methanation unit. Developing scenarios and flow sheets and using mass and energy balance, the technical performance of the concept is investigated. A plant capacity of $10 \mathrm{MWel}$ is considered. An annual production of 1104 metric tons per year (Mt/a) hydrogen and thus of 5888 Mt/a methane is reached. The overall plant efficiency is calculated to be $38 \%$. The combination of wind power and biogas offers thus many advantages which can facilitate the penetration of the wind resource and the progression to the hydrogen economy.

\section{Keywords}

Hydrogen, Methane, High Temperature Steam Electrolysis, Wind Energy, Biogas, Renewable Electricity

\section{Introduction}

Global warming and climate change issues are one of the greatest threats to this planet. There is now scientific

How to cite this paper: Monnerie, N., et al. (2014) Coupling of Wind Energy and Biogas with a High Temperature Steam Electrolyser for Hydrogen and Methane Production. Green and Sustainable Chemistry, 4, 60-69. 
consensus that energy based on the deployment and consumption of conventional fossil resources is not environmental-friendly energy for the human development. Many concerns have been dominated by the global concerns of over-population, pollution, water depletion and climate change. The exploitation of renewable energy sources has gained enormous interest during recent years with the ultimate purpose to move towards increased energy sustainability and eventually complete independence from fossil fuel energy and should be thus the priority for human development. The necessities of clean and sustainable energy as well as the reduction of the emissions require new production technology.

In this setting, hydrogen economy is an important energy system for the future. Renewable energy will be used to generate hydrogen as energy carrier. Hydrogen is an ideal energy carrier and an entirely renewable fuel if produced from green electricity and water. It can be stored and transported over large distances by using pipelines or trucks. Moreover, hydrogen is not only a fuel but also an industrial process gas, which can be converted for example into synthetic fuels like methane.

In fact, methane is easier to handle and can be stored more easily than hydrogen. Moreover, the transportation and storage infrastructure are already present and mature. Huge storage capacity in the form of storage tanks and pipeline grids are already available in many countries capable to store a significant share of the country's energy consumption. Methane is essentially used for heating and cooking but also as transport fuel as an interim solution. It can also be used as industrial fuel or transformed into other fuels [1].

Electrolysis is an electrochemical process converting electrical energy into chemical energy. Water electrolysis consists of decomposing a molecule of water into hydrogen and oxygen and can produce largely carbon-free hydrogen using electricity from $\mathrm{CO}_{2}$-free energy sources [2] [3]. Electrolysis can contribute to increasing the share of renewable energy in the total energy system. Electrolysis products can be stored and used for energy production or in the transport sector. In the High Temperature Steam Electrolyser (HTSE) a part of the energy demand of the electrolysis reaction is provided by heat saving a part of the electricity demand. It has the advantage of a higher energy efficiency compared to the low-temperature electrolysis because of reduced cell potential. HTSE is a promising process for emission-free hydrogen production from water and offers positive perspectives for efficient use of renewable energy sources. An energy system with the generation of hydrogen from renewable sources is self-sufficient and a clean $\mathrm{CO}_{2}$-neutral alternative for sustainable development [4]-[6]. In the frame of the European Fuel Cell and Hydrogen Joint Undertaking (FCH JU) project ADEL (Advanced Electrolyser for hydrogen production with renewable energy sources) the coupling between the HTSE unit and renewable heat and power sources have been analyzed and quantified. Among the renewable sources, wind power can be used to generate hydrogen. Windmills have been used for power production for a long time. Among renewable energy, wind has besides solar energy the greatest capacities in terms of supply for the future energy mix. Wind power has a number of particularities mainly due to its variable nature. It is a diffuse energy that cannot be stored easily. Thus it is interesting to convert wind power to hydrogen via water electrolysis or in particular via HTSE to store wind power in the form of transportable and useful chemical energy. The coupling of HTSE with solar concentrating energy systems has been analysed in [7] and many studies have focused on the possibility of hydrogen production using wind power and low temperature water electrolysis [8]-[10] or combining nuclear energy and high temperature steam electrolysis [11]. The feasibility of biogas upgrading to pipeline quality by means of solid oxide electrolysis has been recently studied by the firm Haldor Topsoe and the research department of the technical university of Denmark Riso DTU [12]. However, they have not considered the use of sweep gas in the process, although it was shown that sweep gas is necessary in order to remove the excess oxygen evolved on the anode side of the electrolyser [13]. Even if it is desirable to work without sweep gas from the standpoint of overall process efficiency, there are still significant technical issues due to the handle of hightemperature pure oxygen. This present paper analyses the overall process for the hydrogen production via an HTSE coupled with wind energy, including the use of sweep gas, and the later one methane production from biogas and hydrogen via the coupling of this system (HTSE and wind) with a methanation unit. This includes the simulation of the plant and the analysis of its technical performance. The overall purpose of this study is to find and define in detail a concept to couple a HTSE with wind power in order to convert the renewable electricity in green hydrogen, which will be fed to a methanation unit in order to produce methane as bio fuel and as a long-term storage medium for the energy sector. This concept offers a solution to the challenge of integrating more and more renewable energy into the global energy mix. The paper is structured as follows: Section 2 presents a description of the studied technology and of the flow sheet of the process. Section 3 shows the results of the simulation and discusses them. Finally the conclusion will indicate the most important outcomes of this 
study and proposals for further works.

\section{Description of the Technology}

\subsection{Concept}

The objective of the process presented in this paper is to couple a HTSE with wind energy and biogas in order to produce methane as green fuel. The core part of such process is the HTSE. It is made up of the oxy-reduction of water molecules, driven by a direct electric current. The hydrogen obtained has a high purity. The advantage of the HTSE working at $700^{\circ} \mathrm{C}$ is that its electricity consumption is lower than the one of a low temperature electrolyser (PEM or alkaline). Moreover the improvement of reaction kinetics at high temperature enhances the process efficiency. This type of process could enable a large scale hydrogen production in the future [14]. In the scenario developed and described in this paper, the electricity required for the HTSE is stemming from a wind turbine while the water is evaporated by the heat stemming from a methanation unit. This idea is represented schematically in Figure 1. The hydrogen produced by the HTSE is then sent to a methanation unit in order to produce methane following the Sabatier process, which is nowadays commercially used and which consists of the reaction of hydrogen with carbon dioxide. Actually, methane can be stored more easily than hydrogen. Its transportation, storage and usage are mature and well established e.g. in form of pipeline grids, gas tanks, gas power plants, chemical industries.

Huge storage capacity in the form of storage tanks and pipeline grids are already available in many countries capable to store a significant share of the country's energy consumption.

The concept is thus based on a traditional wind turbine coupled with a HTSE, combined with a methanation unit situated near the natural gas pipeline. A plant capacity of 10 MWel is considered. Figure 2 shows the scheme of the plant. The overall system consists of the four following main sections: the HTSE unit, the wind turbine system, the heat recovery system, and the methanation unit.

\subsection{HTSE Unit Description}

The process of intermediate temperature steam electrolysis is the following:

Cathode

$$
\mathrm{H}_{2} \mathrm{O}_{(g)}+2 e^{-} \rightarrow \mathrm{O}^{2-}+\mathrm{H}_{2(g)}
$$

Anode

$$
\mathrm{O}^{2-} \rightarrow \frac{1}{2} \mathrm{O}_{2(g)}+2 e^{-}
$$

At the cathode, the water molecule is dissociated because of the electrical current and the heat provision, in order to form a molecule of hydrogen and an oxygen ion $\mathrm{O}^{2-}$. Under the effect of the electrical field, the ion $\mathrm{O}^{2-}$ goes through the electrolyte and migrates to the anode where its oxidation produces an oxygen molecule $\mathrm{O}_{2}$.

The HTSE works in the thermoneutral mode, which corresponds to an operation in which electrolysis needed heat is brought by all the overvoltages present in the cell. In this mode, outlet gases $\left(\mathrm{H}_{2} / \mathrm{H}_{2} \mathrm{O}\right.$ and $\left.\mathrm{O}_{2}\right)$ have the same temperature as the inlet gases $\left(\mathrm{H}_{2} \mathrm{O} / \mathrm{H}_{2}\right)$. The operating temperature of the electrolyser is a key factor in terms of efficiency of the HTSE process. A high operating temperature leads to the degradation of the solid oxide electrolysis cell but a low operating temperature has a negative influence on the efficiency of the stack. It was thus decided in the frame of the European project ADEL [15] to operate the electrolysis cell at $973 \mathrm{~K}$, which represents a good compromise regarding the durability and the efficiency of the stack.

To assure sufficient lifetime of the stack components, the steam conversion is limited to $60 \%$.

The product gas from the electrolyser is led to the heat recovery system where it gives off heat to the incoming steam.

Use of sweeping air to flush the produced oxygen from the cathode is favoured, in order to avoid safety issues of handling pure oxygen at $973 \mathrm{~K}$. The sweeping air flow rates should be minimized in order to optimize system efficiency and limit the size of high-temperature heat exchangers. The system design has been based on a molar air-steam ratio of unity.

The main input data for the electrolyser are summarized in Table 1. The specifications are based on the as 


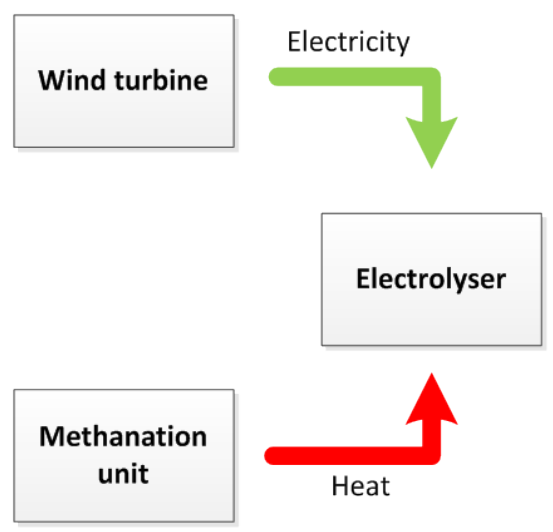

Figure 1. Electricity and heat distribution to the electrolyzer.

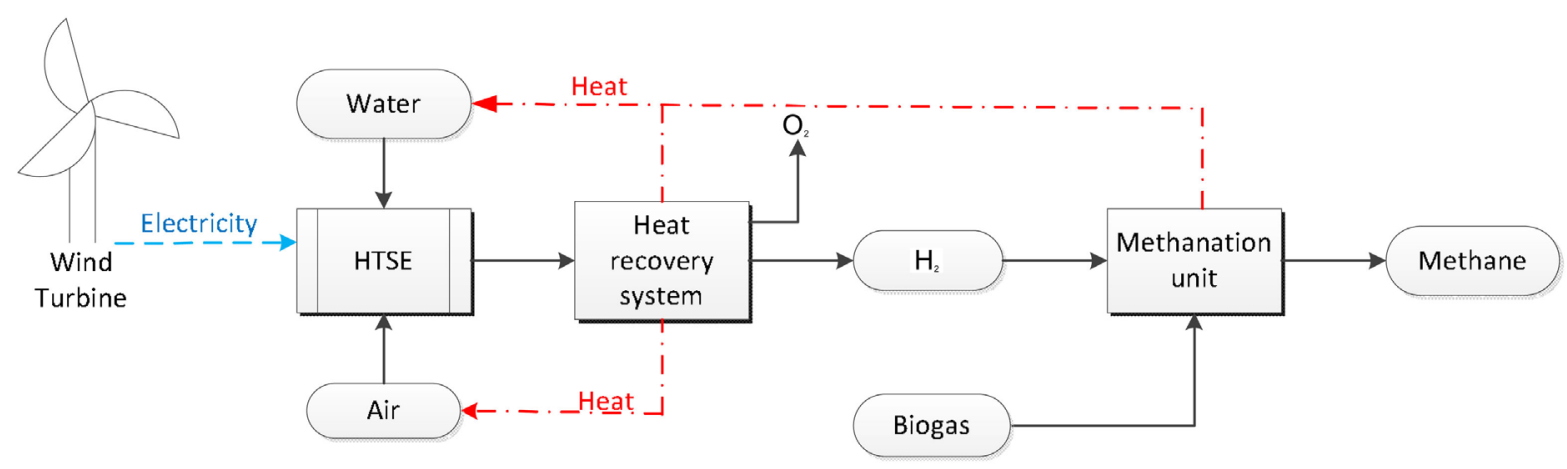

Figure 2. Scheme of the wind turbine coupled with the HTSE.

Table 1. Main input data for the electrolyser.

\begin{tabular}{|c|c|}
\hline Total capacity & 10 MWel \\
\hline Mode & Thermoneutral \\
\hline Sweep gas & Air \\
\hline Sweep gas/cathode stream ratio & $1: 1$ \\
\hline Steam conversion rate & $60 \%$ \\
\hline Inlet/outlet cathode temperature & $973 \mathrm{~K}$ \\
\hline Inlet/outlet anode temperature & $973 \mathrm{~K}$ \\
\hline $\mathrm{H}_{2} \%$ vol at cathode inlet & $10 \%$ \\
\hline System inlet pressure air stream & $100 \mathrm{kPa}$ \\
\hline System inlet temperature air stream & $298 \mathrm{~K}$ \\
\hline System inlet pressure water make-up stream & $100 \mathrm{kPa}$ \\
\hline System inlet temperature water makeup stream & $298 \mathrm{~K}$ \\
\hline
\end{tabular}

sumptions and results of project ADEL [7].

Electrolyzer systems consist of multiple parallel units. Each unit of the electrolyser consists of 110 parallel stacks, each of which requires $4.5 \mathrm{kWel}$. As a result, the total amount of power required by each unit is approximately $500 \mathrm{kWel}$. The case presented here requires thus 20 units.

\subsection{Wind Turbine System}

The amount of energy (MWh) that a wind turbine produces each year depends on many parameters, but the most important factors are the wind speed at hub-height, and the size and type of the turbine. Although there are many different wind turbine configurations, most of them can be classified as either Horizontal-Axis Wind Turbines 
(HAWTs), which have blades that rotate around a horizontal axis parallel to the wind, or Vertical-Axis Wind Turbines (VAWTs), which have blades that rotate around a vertical axis. The HAWT rotor is placed on the top of a tall tower, which allows to access to stronger winds. The most common type of modern HAWT is the classic "Danish" design of three-blade, upwind and pitch regulated concept. The wind turbine used in the hybrid plant to provide electrical energy to the hydrogen production plant is a horizontal axis wind turbine.

\subsection{Heat Recovery System}

The gases at the outlet of the HTSE stack are coupled with a heat recovery system. This heat recovery system consists of heat exchangers, where steam entering the electrolyser is heated up to the operating temperature of the electrolyser, which has been set at $973 \mathrm{~K}$. The heat of the outlet flows is thus recovered. An electrical heater is necessary in order to reach the operating temperature of the electrolyser. A second electrical heater is added to heat the sweep gas to $973 \mathrm{~K}$ if it is necessary for the transient conditions. Thus it enables to control the sweep gas temperature and to guarantee fixed conditions for the sweep gas in the electrolyser. The heat recovery system including the one of the methanation unit does enable to evaporate and heat the water needed for the electrolyser but there is not enough heat to entirely heat the sweep gas which is considered to be needed.

\subsection{Methanation Unit}

Hydrogen is used for the production of methane from the $\mathrm{CO}_{2}$ content of biogas applying the Sabatier process. The Sabatier process consists of the reaction of hydrogen with carbon dioxide. This reaction takes place in the presence of nickel catalyst at higher temperature and pressure. The Sabatier process is described by the following reaction:

$$
\mathrm{CO}_{2}+4 \mathrm{H}_{2} \rightarrow \mathrm{CH}_{4}+2 \mathrm{H}_{2} \mathrm{O}
$$

Thus the carbon dioxide containing in the biogas is transformed into methane thanks the hydrogen produced by the HTSE.

\subsection{Flow Sheet of the Process}

The commercial tool Aspen Plus has been used for the steady state simulation of the overall process. Figure 3 shows the process flow diagram of the plant.

Electricity for the electrolyser is produced by the wind turbine. Liquid water enters through the water pump (PUMP1) and is evaporated in the evaporators (EVAPORA1, EVAPORA2, EVAPORA3). These use recovered heat from the methanation unit and from the output streams of the HTSE (STEAMSPL-MEM) which is fed with steam at $973 \mathrm{~K}$ and $150 \mathrm{kPa}$. Before entering the electrolyser, the steam is split into two sub-streams (WATER 3 and WATER 4) which are overheated in the heat exchangers (SUPERHX2 and SUPERHX3) by the streams leaving the electrolyser, before being mixed again. The steam is also mixed with a part of the cathode outlet mixture (produced hydrogen and unreacted steam) in order to have a feed stream of $90 \%$ vol water and $10 \%$ vol hydrogen to ensure reducing conditions and prevent oxidation of the cathode. The steam is supplied to the cathode side and is split into hydrogen and oxygen ions within the HTSE. The oxygen ions are transferred through the electrolyte to the anode side, where they release electrons and form oxygen molecules. The product gas from the electrolyser is led to the heat recovery system where it gives off heat to the incoming steam. Excess water is condensed and hydrogen is compressed to $3000 \mathrm{kPa}$. Hydrogen is then sent to the methanation unit (METHA) for the production of methane with carbon dioxide $\left(\mathrm{CO}_{2}\right)$-rich biogas following the Sabatier process. The produced water from the Sabatier process can be recycled back to the electrolysis stage, reducing the need of new pure water. The heat which accompanied the methanation reaction is used to evaporate the water needed for the HTSE. The mechanical efficiency of the pumps is considered to be $90 \%$ while the compressors have been simulated with an isentropic efficiency of $75 \%$.

The biogas consists primarily of methane $\left(\mathrm{CH}_{4}\right)$ and carbon dioxide $\left(\mathrm{CO}_{2}\right)$. It may have small amounts of hydrogen sulphide $\left(\mathrm{H}_{2} \mathrm{~S}\right)$ and in some cases siloxanes. Table 2 shows the typical composition of biogas [16].

These impurities have negative effects on the methanation unit and should be eliminated.

$\mathrm{H}_{2} \mathrm{~S}$ is removed in purification column, where the biogas is purified with cooled water under pressure. Water is supplied from cooling system from the top of the column in the reverse direction to the biogas flow. The $\mathrm{H}_{2} \mathrm{~S}$ removal process is due to its solubility in water. The column is filled with special material in order to secure 


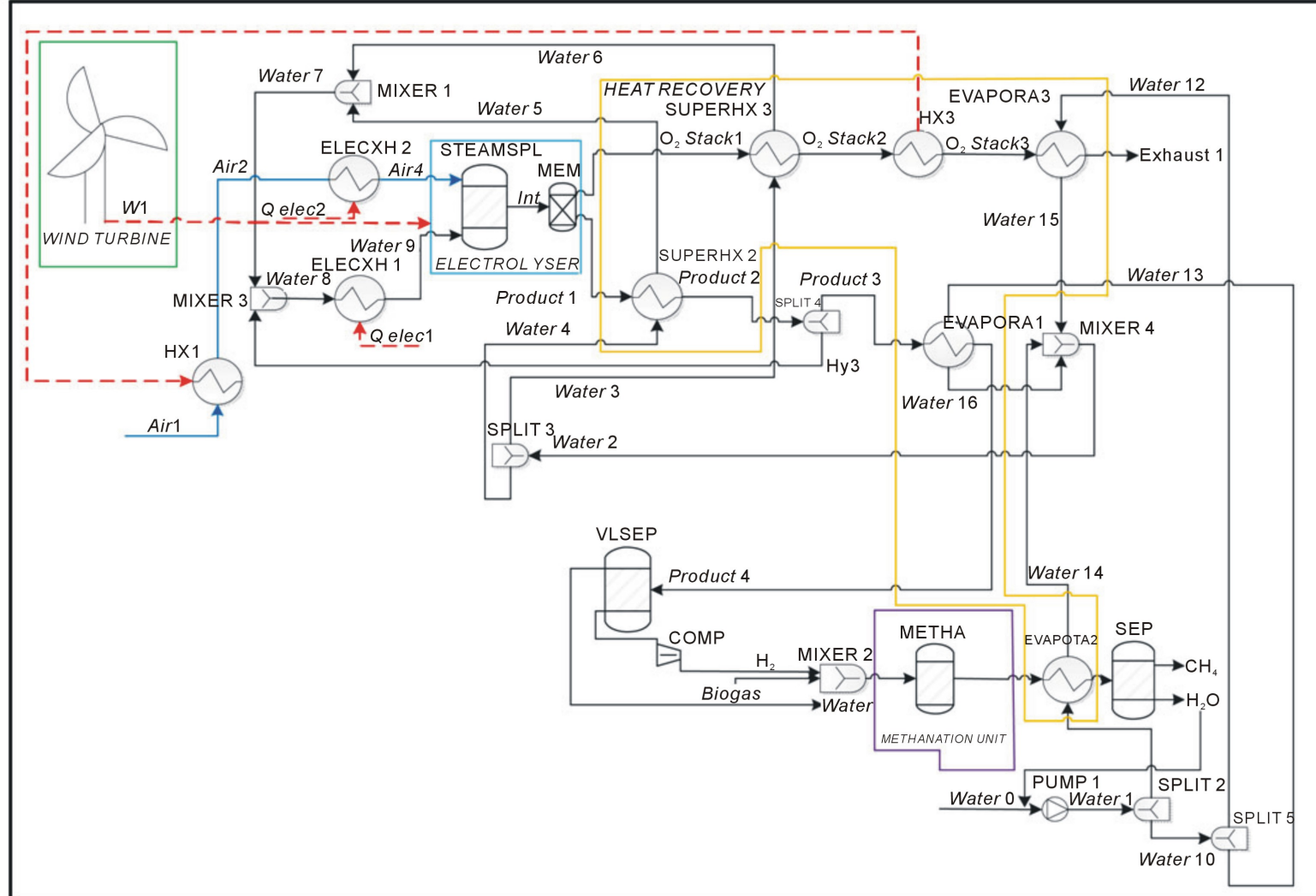

Figure 3. Scheme of the wind turbine coupled with the ITSE and combined with a methanation unit.

Table 2. Typical composition of biogas.

\begin{tabular}{cc}
\hline Compound & Concentration [Vol. \%] \\
Methane $\left(\mathrm{CH}_{4}\right)$ & $55-70$ \\
Carbon dioxide $\left(\mathrm{CO}_{2}\right)$ & $30-45$ \\
Nitrogen $\left(\mathrm{N}_{2}\right)$ & $0-5$ \\
Water $($ vapour $)$ & $1-5$ \\
Siloxanes $\left(\mathrm{C}_{\mathrm{n}} \mathrm{H}_{2 \mathrm{n}+1} \mathrm{SiO}\right)$ & $0-50 \mathrm{mg} / \mathrm{m}^{3}$ \\
Oxygen $\left(\mathrm{O}_{2}\right)$ & $<1$ \\
Hydrogen sulfide $\left(\mathrm{H}_{2} \mathrm{~S}\right)$ & $0-0.5$ \\
\hline
\end{tabular}

good heat conductivity. Water that is used for biogas purification contains dissolved $\mathrm{H}_{2} \mathrm{~S}$ is directed to a regeneration column, where the gas is extracted from the water. Finally, the treated water is supplied again to the inlet of the purification column.

The purification unit was not considered in this study. Therefore, the biogas feedstock is dry and has a $\mathrm{CH}_{4}$ content of $65 \mathrm{vol} . \%$ and a $\mathrm{CO}_{2}$ content of $35 \mathrm{vol. \%}$.

\section{Results of the Simulation and Discussion}

The nominal conditions of the combined plant and the heat process transfer are assessed. In nominal conditions, it was assumed that $10 \mathrm{MWel}$ will be generated by the wind turbine. The performance of the combined plant under this assumption is analysed.

In order to analyse the combined plant under nominal conditions the simulation tool Aspen Plus is used. Starting from the HTSE conditions, this software allows obtaining the pressure, the temperature and the flow of the different process streams.

The results of the steady state simulation carried out for a $10 \mathrm{MWel}$ plant and concerning the energy con- 
sumptions of core components are presented in Table 3.

According to Table 3, the power consumed by the electrical heaters is about $1.5 \mathrm{MW}$.

The results of the main streams of the process have been summarized in the Table 4 .

Starting from the nominal conditions, the annual yield analysis is performed and the performance of the combined power plant including a wind turbine and a methanation unit is calculated. Table 5 includes the values obtained by the simulation that allow the performance assessment under nominal conditions.

Table 3. Energy balance in the nominal conditions.

\begin{tabular}{cc}
\hline Component (component ID) & Heat duty/Power [MW] \\
\hline Wind turbine (TURBINE1) & 10 \\
Heat exchangers & 0.73 \\
SUPERHX2 & 0.36 \\
SUPERHX3 & 0.38 \\
EVAPORA1 & 1.61 \\
EVAPORA2 & 0.7 \\
EAVPORA3 & 0.28 \\
Electrical heaters & 1.2 \\
ELECHX1 & \\
ELECHX2 &
\end{tabular}

Table 4. Mass balance in the nominal conditions.

\begin{tabular}{|c|c|c|c|c|c|}
\hline Section & Stream name & Mass flow [kg/h] & Mole flow $[\mathrm{kmol} / \mathrm{h}]$ & Pressure [bar] & Temperature $\left[{ }^{\circ} \mathrm{C}\right]$ \\
\hline \multirow{5}{*}{$\begin{array}{l}\text { Electrolysis } \\
\text { block }\end{array}$} & Water7 & 3729 & 207 & 1.5 & 624 \\
\hline & Water8 & 3997 & 243 & 1 & 592 \\
\hline & Water9 & 3997 & 243 & 1 & 700 \\
\hline & Air4 & 5972 & 207 & 1 & 700 \\
\hline & Hy3 & 268 & 36 & 1 & 369 \\
\hline \multirow{7}{*}{ Heat recevory } & $\mathrm{O}_{2}$ stack 1 & 8181 & 276 & 1 & 700 \\
\hline & $\mathrm{O}_{2}$ stack2 & 8181 & 276 & 1 & 559 \\
\hline & $\mathrm{O}_{2}$ stack3 & 8181 & 276 & 1 & 350 \\
\hline & Product1 & 1788 & 243 & 1 & 700 \\
\hline & Product2 & 1788 & 243 & 1 & 370 \\
\hline & Product3 & 1520 & 207 & 1 & 370 \\
\hline & Product4 & 1520 & 207 & 1 & 161 \\
\hline \multirow{4}{*}{$\begin{array}{l}\text { Hydrogen seperation } \\
\text { and methanation }\end{array}$} & $\mathrm{H}_{2}$ & 388 & 144 & 30 & 146 \\
\hline & Biogas & 2546 & 98 & 1 & 25 \\
\hline & $\mathrm{H}_{2} \mathrm{O}$ & 1428 & 79 & 30 & 30 \\
\hline & $\mathrm{CH}_{4}$ & 1472 & 92 & 30 & 30 \\
\hline
\end{tabular}

Table 5. Main simulation results in nominal conditions.

\begin{tabular}{|c|c|c|}
\hline Lower heating value & 239.86 & $\mathrm{~kJ} / \mathrm{mole}_{2}$ \\
\hline Electrical power & 10000 & $\mathrm{~kW}$ \\
\hline Electrical heater (air) & 1200 & $\mathrm{~kW}$ \\
\hline Electrical heater (steam) & 288 & $\mathrm{~kW}$ \\
\hline Inlet air mass flow & 5972 & $\mathrm{~kg} / \mathrm{h}$ \\
\hline Anode outlet temperature & 973 & $\mathrm{~K}$ \\
\hline Inlet steam $+\mathrm{H}_{2}$ mass flow & 3997 & $\mathrm{~kg} / \mathrm{h}$ \\
\hline Cathode outlet temperature & 973 & K \\
\hline Outlet $\mathrm{H}_{2}+$ steam flow & 1788 & $\mathrm{~kg} / \mathrm{h}$ \\
\hline Outlet $\mathrm{O}_{2}+$ air mass flow & 8181 & $\mathrm{~kg} / \mathrm{h}$ \\
\hline $\mathrm{H}_{2}$ molar flow & 138 & $\mathrm{kmol} / \mathrm{h}$ \\
\hline $\mathrm{CH}_{4}$ molar flow & 92 & $\mathrm{kmol} / \mathrm{h}$ \\
\hline
\end{tabular}


The simulation of the combined plant under nominal conditions leads to a hydrogen production rate of 276 $\mathrm{kg} / \mathrm{h}$, which corresponds to $1472 \mathrm{~kg} / \mathrm{h}$ of methane. Thus, a production of 1104 metric tons per year (Mt/a) of hydrogen can be expected from the combined plant, assuming a capacity factor of $50 \%$ for the wind turbine, which correspond to $5888 \mathrm{Mt} / \mathrm{a}$.

The overall efficiency of the HTSE process coupled to the wind turbine and the methanation unit can be defined as the ratio of the energy carried by unit amount of produced methane $n_{\mathrm{CH}_{4} \text {,produced }}$, in terms of higher heating value of methane $\left(\mathrm{HHV}_{\mathrm{CH}_{4}}=889 \mathrm{~kJ} / \mathrm{mol}\right)$, to the total energy needed corresponding to the wind energy in form of kinetic energy including the electrical power power $\mathrm{P}_{\mathrm{el}}$,heaters for the electrical heaters. The kinetic energy of wind can be calculated as the ratio of the generated electrical power to the efficiency of the wind turbine.

The efficiency of the overall process (wind to methane) can be expressed by the following equation:

$$
\eta_{\text {overall }}=\frac{\dot{n}_{\mathrm{CH}_{4}, \mathrm{produced}} \mathrm{HHV}_{\mathrm{CH}_{4}}}{\frac{P_{e l, W T}}{\eta_{W T}}+P_{\text {el, heaters }}}
$$

According to the simulation results and assuming a wind turbine efficiency of $50 \%$, the overall efficiency of the combined plant is calculated at $38 \%$.

The efficiency of the HTSE process can be defined as the ratio of the energy carried by unit amount of produced hydrogen, in terms of low heating value of hydrogen ( $L H V_{\mathrm{H}_{2}}=239.86 \mathrm{~kJ} / \mathrm{mol}$ ), to the energy input of the elecrolysis process, which is in this case the electrical power consumed by the electrolyzer.

The efficiency of the HTSE process can be expressed as follows:

$$
\eta_{\text {HTSE }}=\frac{\dot{n}_{\mathrm{H}_{2}} L H V_{\mathrm{H}_{2}}}{P_{\mathrm{el}}}
$$

According to the simulation results, the electrical power consumed by the electrolysis unit is $10 \mathrm{MWel}$ allowing the production of a hydrogen flow rate of $138 \mathrm{kmol} / \mathrm{h}$. The efficiency is given by Equation (5) and is $92 \%$.

In fact the direct coupling of a HTSE with a wind turbine implies a variable power output. One possibility to lower the variability of the power supply to the HTSE is to combine the system with another renewable electricity source. Biogas is a renewable energy source and an obvious alternative to fossil fuels. The hybridisation of wind power with biogas energy could lower the variability of the power supply with electricity provided by the combustion of biogas and by the wind. The integration of wind power and biogas energy in a proper combination to form a hybrid system can avoid the intermittent operation of the HTSE with a highly variable power input from the wind turbine. The advantage of the hybridisation of a wind turbine with a biogas combustion unit is to produce a quasi constant quantity of electricity for the electrolyser. In fact, when the wind does not sufficiently blow and the electricity produced does not reach the quantity needed for the electrolyser, some additional electricity can be produced by a biogas combustion unit in order to have a constant supply for the electrolyser. In this manner the quantity of hydrogen produced, and consequently of methane, is still constant. Moreover, the biogas unit can deliver the required heat for generating and overheating the steam. This concept has ben also investigated for a plant capacity of $10 \mathrm{MWel}$. In this scenario, the electricity required for the HTSE is provided by a wind turbine but also by a biogas combustion unit, in order to lower the variability of the power supply. In this case, a fifth section consisting in a Combined Heat and Power (CHP) biogas unit is added. The use of CHP designs is indeed very common. The process heat is used for hot sweep gas supply, and the electricity generated will be used in the plant for the electrolyser when the electricity coming from the wind turbine is not enough. A part of the biogas is also used after the production of hydrogen in the methanation unit in which methane is produced following the Sabatier process with the hydrogen obtained from the electrolyser. The simulation showed that combined hybrid plant (Wind Turbine and Biogas unit + HTSE) produces $2208 \mathrm{Mt} / \mathrm{a}$ of hydrogen corresponding to 11,776 ton of methane per year. This is twice as much as the production of the plant presented before. However, the nominal efficiency of this overall process is calculated to be $11 \%$ which is due to the higher biogas consumption and which is much lower than the efficiency of the process plant considered before. Moreover, the costs due to the biogas combustion unit can represent a part non negligible in the investment costs. So the first concept presented before in details in this paper is preferred. Indeed the last research results showed that 
the HTSE can perform load changes and is thus capable to work with variable electricity input [17].

\section{Conclusions}

In this paper, the wind energy coupled to a HTSE has been investigated. It has been shown in this study that hydrogen can be produced by a HTSE combined with a wind turbine, and used for the production of methane, which is then injected in the natural gas grid. Thus the combination of wind power and biogas offers many advantages in terms of the electricity generation by the wind. An assessment of the combined plant energy performance in nominal conditions has been done. From this analysis, it is concluded that the annual hydrogen production of a 10 MWel Electrolyser coupled with a wind turbine makes this plant to be considered as the hydrogen source for methane production. For a 10 MWel HTSE plant, an annual production of $1104 \mathrm{Mt} / \mathrm{a}$ hydrogen and thus of $5888 \mathrm{Mt} / \mathrm{a}$ methane is reached, which corresponds to an overall efficiency of $38 \%$. As the electricity is provided only by the wind turbine, the quantity of hydrogen produced varies with the time and is lower over the year as compared with a HTSE coupled to a wind turbine and a biogas unit combustion providing heat but also electricity for the HTSE but the overall efficiency of the presented plant is much better.

Thinking of future work, the demonstration of the durability of the HTSE system has to be done. Moreover, cost estimation has to be calculated to improve the economy of the process. With increasing interest in hydrogen and in renewable energy, this concept will draw more and more attention.

\section{Acknowledgements}

The authors of this paper gratefully acknowledge the co-funding of the project ADEL by the FCH JU (Grant agreement no. 256755). Specials thanks are due to ADEL Project partners Jan Peter Brouwer and Michael Walter (HyGear, The Netherlands) for their contribution providing information on SOE stack architecture and performance.

\section{References}

[1] Barton, J. and Gammon, R. (2010) The Production of Hydrogen Fuel from Renewable Sources and Its Role in Grid Operations. Journal of Power Sources, 195, 8222-8235. http://dx.doi.org/10.1016/j.jpowsour.2009.12.100

[2] Brisse, A., Schefold, J., Stoots, C. and O’Brien, J. (2010) Electrolysis Using Fuel Cell Technology. In: Lehnert, W. and Steinberger-Wilckens, R., Eds., Innovation in Fuel Cell Technologies, RSC Publishing, Cambridge, 263-286.

[3] Zahid, M., Schefold, J. and Brisse, A. (2010) High-Temperature Water Electrolysis Using Planar Solid Oxide Fuel Cell Technology: A Review. In: Stolten, D., Ed., Hydrogen and Fuel Cells, Fundamentals, Technologies and Applications, Wiley-VCH, Weinheim, 227-242.

[4] Shakya, B.D., Aye, L. and Musgrave, P. (2005) Technical Feasibility and Financial Analysis of Hybrid Wind-Photovoltaic Systems with Hydrogen Storage for Cooma. International Journal of Hydrogen Energy, 30, 9-20. http://dx.doi.org/10.1016/j.ijhydene.2004.03.013

[5] Gazey, R., Salman, S.K. and Aklil-D’Halluin, D.D. (2006) A Field Application Experience of Integrating Hydrogen Technology with Wind Power in a Remote Island Location. Journal of Power Sources, 157, 841-847. http://dx.doi.org/10.1016/j.jpowsour.2005.11.084

[6] Gonzalez, A., McKeogh, E. and Gallchóir, B.O. (2003) The Role of Hydrogen in High Wind Energy Penetration Electricity Systems: The Irish Case. Renewable Energy, 29, 471-489. http://dx.doi.org/10.1016/j.renene.2003.07.006

[7] Houaijia, A., Monnerie, N., Roeb, M., Sattler, C., Sanz-Bermejo, J., Romero, M., Canadas, I., Drisaldi Castro, A., Lucero, C., Palomino, R., Petipas, F. and Brisse, A. (2013) Coupling Heat and Electricity Sources to Intermediate Temperature Steam Electrolysis. Journal of Energy and Power Engineering, 7, 2068-2077.

[8] Green, R., Hu, H. and Vasilakos, N. (2011) Turning the Wind into Hydrogen: The Long-Run Impact on Electricity Prices and Generating Capacity. Energy Policy, 39, 3992-3998. http://dx.doi.org/10.1016/j.enpol.2010.11.007

[9] Greiner, C.J., Korpås, M. and Holen, A.T. (2007) A Norwegian Case Study on the Production of Hydrogen from Wind Power. International Journal of Hydrogen Energy, 32, 1500-1507.

[10] Gökcek, M. (2010) Hydrogen Generation from Small-Scale Wind-Powered Electrolysis System in Different Power Matching Modes. International Journal of Hydrogen Energy, 35, 10050-10059. http://dx.doi.org/10.1016/j.ijhydene.2010.07.149

[11] Utgikar, V. and Thiesen, T. (2006) Life Cycle Assessment of High Temperature Electrolysis for Hydrogen Production via Nuclear Energy. International Journal of Hydrogen Energy, 31, 939-944. 
http://dx.doi.org/10.1016/j.ijhydene.2005.07.001

[12] Hansen, J.B. (2013) The Role of Solid Oxide Electrolysis in the Context of Future Energy Scenarios in Denmark. 2nd ADEL International Workshop, 8-9th May 2013.

[13] O’Brien, J., Herring, J., Stoots, C., McKellar, M., Harvego, E., Condie, K., Housley, G. and Hartvigsen, J. (2009) Status of the INL High-Temperature Electrolysis Research Program-Experimental and Modeling.

[14] Elangovan, S. and Hartvigsen, J. (2007) High-Temperature Electrolysis. Materials for the Hydrogen Economy, 3, 6-80.

[15] (2013) JTI-FCH Project ADEL. www.adel-energy.eu

[16] http://www.biomassenergy.gr/en/

[17] Petipas, F., Fu, Q., Brisse, A. and Bouallou, C. (2013) Transient Operation of a Solid Electrolysis Cell. International Journal of Hydrogen Energy, 38, 2957-2964. http://dx.doi.org/10.1016/j.ijhydene.2012.12.086 